\title{
Acceptance, Quality and Trust Factors - Conceptual Model for Open Government Data Potential Use
}

\author{
Noor Zalina Zainal, Husnayati Hussin, Mior Nasir Mior Nazri \\ Dept of Business and Management, Universiti Teknologi MARA, Puncak Alam, Malaysia \\ zalinazainal@salam.uitm.edu.my \\ Dept of Information and Communication Technology, International Islamic University Malaysia, Kuala Lumpur, Malaysia \\ husnayati@iium.edu.my \\ Dept of Information and Communication Technology, International Islamic University Malaysia, Kuala Lumpur, Malaysia \\ miornasir@iium.edu.my
}

\begin{abstract}
To implement Big Data extensively in the public sector, many governments around the world are taking their initiative to ensure that Open Government Data (OGD) is a success. Even though the governments had provided thousands of datasets in the open data website, the level of use of open government data is still a question that has not been resolved. Therefore, the objective of this paper is to propose a new model of measuring the level of use of open government data. By integrating the Unified Theory of Acceptance and Use of Technology (UTAUT), IS Success Model (ISSM) and Trust factors, this new model perhaps can be a major contribution to the governments in ensuring that citizens are getting benefits from the datasets provided in the open data website.
\end{abstract}

Keywords — open government data, UTAUT, IS Success Model, trust, behavioral intention

\section{INTRODUCTION}

Readiness, implementation and impact are the criteria to measure the success and impact of open data provided by the World Wide Web Foundation in the Open Data Barometer Global Report [1]. In 2nd Edition of Open Data Barometer Global Report, Malaysia was stated into the "one-sided country" category which means that citizens engagement are lacking even though the government has taken good initiatives to publish data [2]. Even though the platform of open government data is available for citizens to access it freely, the level of use and level of benefits the citizens gain from the datasets are still unanswered. In other words, the citizens may not be using the data even though the data is available on the website [3].

In the research area, many studies have been conducted in identifying the awareness and readiness level of open government data (OGD) in several countries. Despite though, the study in acceptance of OGD has not been covered widely. Furthermore, the success measure of OGD has not yet been explored comprehensively especially in developing countries. Therefore, this paper attempts to propose a new framework to identify the determinant factors influencing the behavioral intention to use OGD by integrating the acceptance factors, quality factors and trust factors from the perspectives of OGD stakeholders.

\section{LITERATURE REVIEW}

\section{A. Open Government Data}

The definition of open government data basically can be identified as "government data that can be shared with the public, freely access and enable to be manipulated" [4], [5]. According to [6], open data is an open-disclosure data and it is not confidential. In other words, the open government data is made available without any limitations on its usage or distribution. [7] highlighted that open data should be disseminated freely, available on a website to be accessed freely, can be republished, reuse and can be transformed into a new application or products for the benefits of citizens. [8] also mentioned that open data should be able to be used to venture new things, analyzing patterns and trends, and solve complicated problems. Therefore, [1] highlighted that open data must be publicly available for everyone to access and data must be licensed that allows it to be reused.

\section{B. OGD: Open Data Barometer Global Report}

The World Wide Web Foundation has come out with Open Data Barometer (ODB) Global Report, to measure the success and impact of open data initiatives by governments over the world. The ranking was based on the three criteria: 1) Readiness, 2) Implementation and 3) Impact [1]. Readiness refers to the open data initiatives by the governments, 
implementation refers to the success of open data programs taken by governments, and impact relates to the influence of open data towards political, civil society and business environment.

As for Malaysia, the ranking in ODB Global Report is presented below:

TABLE I SUMMARY OF MALAYSIA'S RANKING IN ODB GLOBAL REPORT

\begin{tabular}{|l|c|c|c|}
\hline \multicolumn{1}{|c|}{$\begin{array}{c}\text { ODB } \\
\text { REPORT }\end{array}$} & RANK & $\begin{array}{c}\text { RANK } \\
\text { CHANGE }\end{array}$ & $\begin{array}{c}\text { TOTAL } \\
\text { SCORE }\end{array}$ \\
\hline $\begin{array}{l}1^{\text {st }} \text { Edition } \\
2013\end{array}$ & N/A & N/A & N/A \\
\hline $\begin{array}{l}2^{\text {nd }} \text { Edition } \\
2014\end{array}$ & $\begin{array}{c}41 / 86 \\
\text { countries }\end{array}$ & N/A & 30.76 \\
\hline $\begin{array}{l}3^{\text {rd }} \text { Edition } \\
2015\end{array}$ & $\begin{array}{c}51 / 92 \\
\text { countries }\end{array}$ & -10 & 24.60 \\
\hline $\begin{array}{l}4^{\text {th }} \text { Edition } \\
2016\end{array}$ & $\begin{array}{c}53 / 115 \\
\text { countries }\end{array}$ & -2 & 28.06 \\
\hline
\end{tabular}

From the above table, the number of countries being measured increase by years. In the latest edition of the report, 115 countries have been ranked and Malaysia is in number 53, sharing the place with Paraguay, Latvia, Bolivia and Thailand [9]. In conclusion, Malaysia has to take tremendous action to ensure that the government can increase the rank, by considering the guidelines provided by the World Wide Web Foundation: 1) the open data should benefit citizens, 2) the governments must increase their efforts to ensure that open data is for everyone, and 3) data being published must be accurate and reliable, that suits with people's needs and use.

C. Past Researchers on OGD - Adaption of Theories and Models

The number of researches that focused on the intention to use open government data is still small even though numerous of researches have been conducted to measure the level of use of other information technologies such as egovernment, e-commerce, and online banking. Despite governments have taken very good initiatives to implement open government data in their country, the level of awareness and usage is still unanswered.

In measuring the behavioral intention to use technologies, theories and models related to that objective are adapted by researchers. Theories of acceptance such as Theory of Acceptance Model (TAM), Theory of Planned Behavior (TPB), Theory of Reasoned Action (TRA) have been adapted in numerous studies of identifying the factors influencing the intention to use technologies. Furthermore, Unified Theory of Acceptance and Use of Technology (UTAUT) and Information System Success Model (ISSM) also are the relevant theories in research to measure the behavioral intention to use technologies.

The table below summarizes the literature reviews on behavioral intention to use open government data in few countries, highlighting the adaption of theories and framework that the researchers applied in their study

Table II Literature Reviews on Behavioral Intention to Use

\begin{tabular}{|l|c|c|}
\hline \multicolumn{1}{|c|}{ Models Adapted } & \multicolumn{1}{|c|}{ Country } & Author \\
\hline $\begin{array}{l}\text { IS Success Model } \\
\text { (ISSM) }\end{array}$ & $\begin{array}{c}\text { Moldova } \\
\text { (continent of } \\
\text { Europe) }\end{array}$ & {$[10]$} \\
\hline $\begin{array}{l}\text { Theory of Planned } \\
\text { Behaviour (TPB), IS } \\
\text { Success Model (ISSM), } \\
\text { Trust }\end{array}$ & Indonesia & {$[11]$} \\
\hline $\begin{array}{l}\text { Unified Theory of } \\
\text { Acceptance and Use of } \\
\text { Technology (UTAUT) }\end{array}$ & India & {$[12]$} \\
\hline $\begin{array}{l}\text { Unified Theory of } \\
\text { Acceptance and Use of } \\
\text { Technology (UTAUT) }\end{array}$ & $\begin{array}{l}\text { Conference } \\
\text { Participants }\end{array}$ & {$[13]$} \\
\hline $\begin{array}{l}\text { Unified Theory of } \\
\text { Acceptance and Use of } \\
\text { Technology (UTAUT), } \\
\text { Technology }\end{array}$ & $\begin{array}{c}\text { United } \\
\text { States of } \\
\text { America, } \\
\text { Awitzerland, } \\
\text { Great Britain, } \\
\text { Germany, } \\
\text { Austria }\end{array}$ & \\
\hline
\end{tabular}

The table 3 summarized the categories of IS models and theories:

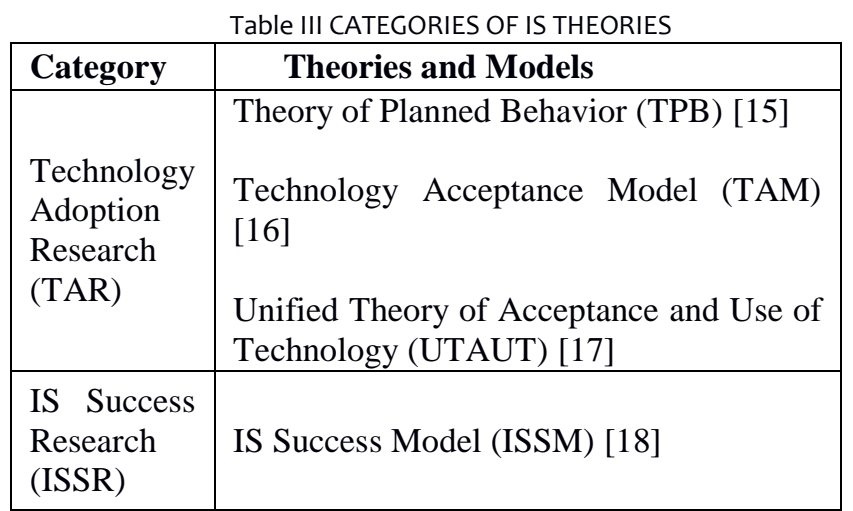

Based on Table 3, according to [19], all the information system (IS) theories and models can be classified into two categories: IS Success Research (ISSR) and Technology Adoption Research (TAR). The ISSR stream focus on the issues of the dependent variable in Management Information System (MIS) researches - focus on the value that is derived from technologies, whilst TAR stream focus on the issues of users' resistance to change - predicting users' behavior on intention to use.

From Table 2, it can be concluded that UTAUT and ISSM are the theories that have been adopted separately in determining the factors that influence the intention to use OGD. However, the integration of both theories in one conceptual model has not yet been studied in the respective area. Hence, this study attempts to integrate both UTAUT 
and ISSM in identifying the determinant factors of behavioral intention to use OGD. Furthermore, by referring to [19], UTAUT and ISSM is the best combination of theories that focus on adoption and the success of the OGD.

\section{THEORETICAL UNDERPINNINGS}

This section highlights the theories and models that are adapted to propose a new conceptual framework to identify factors of behavioral intention to use OGD.

\section{A. Unified Theory of Acceptance and Use of Technology} (UTAUT)

To measure the intention to use the information system, [17] proposed a Unified Theory of Acceptance and Use of Technology (UTAUT). The idea to extend the previous technology acceptance models was to overcome the weaknesses that laid in the models. Basically, the UTAUT model was developed from the combination of eight other theories and acceptance models which are technology acceptance model (TAM), theory of reasoned action (TRA), theory of planned behaviour (TPB), the motivational model $(M M)$, the model of $P C$ utilization (MPCU), the social cognitive theory (SCT), combination model of TAM-TPB (CTAM-TPB), and the diffusion of innovation theory (DOI).

The original UTAUT model by [17] stated that the four constructs related to the behavioral intention to use technology are: 1) performance expectancy, 2) effort expectancy, 3) social influence, and 4) facilitating conditions. Respectively, these four constructs found to be relevant to measure the behavioral intention to use OGD [12], [13].

In the area of OGD, [12] highlighted that UTAUT is the most appropriate model to measure the intention to use the technology. This supports the theory of [17] that about 70 percent of the dimensions influence the behavioral intention to use and accept the technology. Another research conducted by [13] also applied the UTAUT model to identify factors that influencing behavioral intention to use OGD. They highlighted that when the policy-makers have a very good understanding of intention to use OGD by citizens, they will make comprehensive policy mechanisms that can increase the level of acceptance and usage of OGD. Therefore, [13] proposed to use UTAUT to determine factors that influence the acceptance and use of OGD.

\section{B. Information Systems Success Model (ISSM)}

The IS Success Model (ISSM) is a well-known and widely adopted framework for measuring the success or effectiveness of an information system in the organization. This model was first developed by [20] to specifically measuring the success of information system implemented in the organization. The first model consists of six dimensions: 1) System Quality, 2) Information Quality, 3) Use, 4) User Satisfaction, 5) Individual Impact and 7) Organizational Impact. Many researchers tend to use this model and expand the model to suits with different types of technology, to measure their success. [21] in his research then re-specified and extended the original ISSM due to certain confusion in the definition of terms in the original model.

Ten years after, [18] updated their model and came out with six dimensions: 1) System Quality, 2) Information Quality, 3) Service Quality, 4) Use/Intention to Use, 5) User Satisfaction, and 6) Net Benefits. Basically, this model was proposed to measure the success of e-commerce. However, many researchers tried to adapt the model to identify the success measure of other types of information systems such as online banking and e-government. In literature, [19] adopted ISSM and TPB in measuring the organization benefits from the adoption of the information system. [22] in their study also integrate ISSM and UTAUT to measure the loyalty of consumers in mobile banking.

In OGD context, [10] highlighted that ISSM is an appropriate model to measure the success of open data platform because, in the context of $\mathrm{G}_{2} \mathrm{C}$ e-government, they believed that information and service quality have dominant influence on use, user satisfaction and perceived net benefits. However, [11] in their study highlighted that TPB with a combination of quality factors (system quality, information quality and service quality) from ISSM and trust factors is applicable to determine the factors influencing intention to use open data websites.

\section{A. Role of Trust in OGD Context}

Trust towards technology and trust towards government has been proven to be key success factors in egovernment. According to [23], when the citizens trust the government and the technology, they will be more likely to use the e-government services. It is also believed that the trusted party will act in a publicly responsible manner to meet the expectations of the trusting party [23]. A study conducted by [14] proved that trust of the internet has a negative relationship with intention to use open data. Conversely, in open data context, [11] highlighted that trust in technology and trust in government play a big role to influence the trust towards OGD website.

\section{Proposed Conceptual Model}

Despite many researchers have been conducted to identify factors influencing the intention to use information system, only a few have focused on the OGD context. This is perhaps because OGD is relatively fresh to the citizens. Although many governments have taken initiatives to implement open government data in their countries, the level of citizen's awareness of OGD is still unsatisfactory. The intention to use the open data from the OGD platform also remains truncated.

This study attempts to measure the level of behavioral

intention to use OGD as the dependent variable in this model. The influencing factors or the independent variables 
consists of three dimensions: 1) acceptance factors, 2) quality factors, and 3) trust factors. For acceptance factors, the constructs include performance expectancy, effort expectancy, social influence and facilitating conditions. For quality factors, the constructs are information quality, system quality and service quality. For trust factors, the constructs are trust to government and trust to the internet are also independent variables. The trust towards OGD acts as a mediating variable. The proposed model is shown in Figure 1.

\section{VARIABLES AND HYPOTHESES}

Drawing upon previous researches, this paper attempts to integrate acceptance factors from UTAUT, quality factors from ISSM and trust factors in the research framework, to identify the determinant factors that influence the behavioral intention to use OGD. UTAUT is adapted as it explains 70 percent of the aspects that influence the behavioral intention to use and system acceptance [17] Furthermore, UTAUT is a unified model that combines eight theories and models related to acceptance and use of technology [17].

ISSM is also adapted in this study because according to [24], beliefs on information and service quality in $\mathrm{G}_{2} \mathrm{C}$ context, influence most on use, user satisfaction and perceived net benefits. Furthermore, [10] had proved that open government data is related to content and document management, which is aligned with a study on knowledge management validation model by [25], using the ISSM.

Since trust has been identified as a significant aspect that influences the intention to use [11], [23], [26], it is included as one of the variables in the proposed research model.

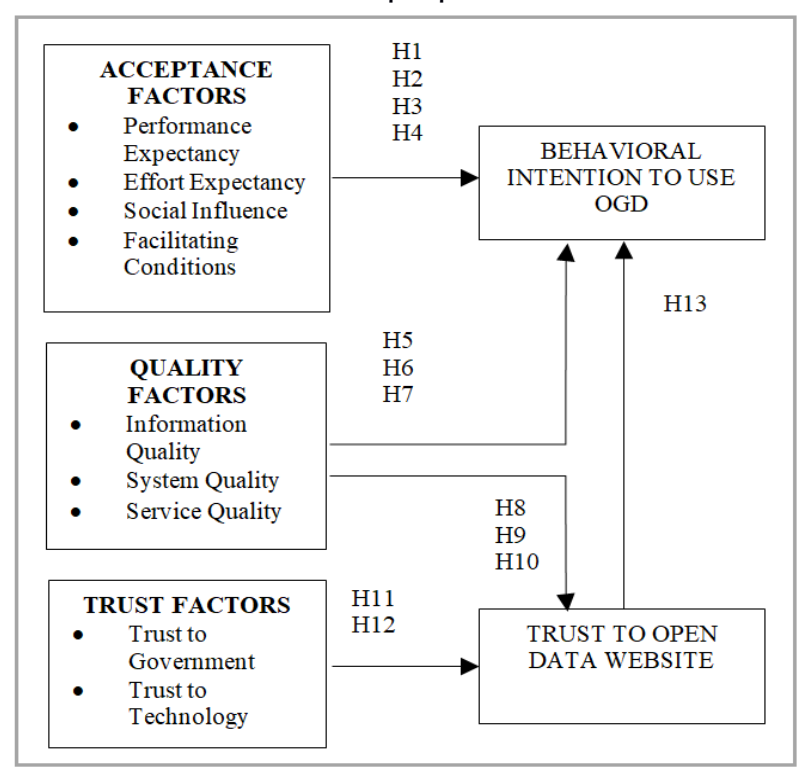

FIG. 1 PRoposed ReSEARCH ModeL

\section{A. Behavioral Intention to Use OGD}

Technologies in a new era such as e-government, elearning, mobile learning, mobile banking and online banking have become the main subjects of research on assessing and measuring the intention to use. Mostly, the objective of the studies is to identify the determinant factors influencing the behavioral intention to use technology, and this led to the action on how to increase the usage level of the particular information system.

In OGD context, research on behavioral intention to use it still in early stage, despite many researchers has concentrated on intention to use information system. This may due to the situation that open government data is still new to the citizens.

According to [15], behavioral intention can be defined as the force of factors that drive someone's intention to perform a specific behavior or doing certain task. Although there are many studies on the acceptance and behavioral intention to use OGD [10]-[13], there have been very few studies on the same issue in developing countries. Past researchers have adapted most of the acceptance models to measure the behavioral intention to use OGD, such as TAM, TPB, UTAUT, ISSM and combination of those models whichever appropriate.

\section{B. Acceptance Factors and Behavioral Intention to Use}

\section{1) Performance Expectancy}

Prior research has proved that performance expectancy are the strongest predictors towards behavioral intention [27], [28]. As defined by [17], performance expectancy is the degree to which an individual trust that the information system that they are using help the person to perform better.

To be specific, few empirical studies that been conducted in the area of OGD support that performance expectancy is the most influenced factors that relate to intention to use OGD [12], [13]. Therefore, this study postulates this hypothesis:

H1: Performance Expectancy positively influences the behavioral intention to use OGD.

\section{2) Effort Expectancy}

According to [12], effort expectancy is related to ease of locating OGD and skills needed to extract and analyze the required data sets. This is aligned with a definition by [17] that effort expectancy is related to the degree of ease of use of technology. However, [13] mentioned that effort expectancy is related to perceived ease of use influence the intention to use the technology, regardless either the technology is easy to use or vice versa. Hence, a person that 
assumes datasets in OGD is easily accessible may believe that using them is effortless. Therefore, this study formulates this hypothesis:

\section{H2: Effort Expectancy negatively influences the intention to use $O G D$.}

\section{3) Social Influence}

In the open data context, social influence may come from the colleagues, supervisors, management, friends, family and people who are important to the user [13]. This is aligned with the definition of social influence by [17]. The influence of using the technology may come from the person surround the user. In fact, the person may show different levels of commitment and satisfaction of technology usage when it is recommended by the social circle [22]. In this study, the social circle is knowingly as the peers, co-workers, teammates (also known as coresearchers) and supervisors or team leaders. Therefore, the hypothesis is formulated as:

$\mathrm{H} 3$ : Social Influence positively influences the intention to use OGD.

\section{4) Facilitating Conditions}

In e-government, facilitating conditions is not the best predictor in intention to use e-government services [29]. However, this is contradictory with studies conducted by [13] and [12]. They highlighted that facilitating conditions influence the intention to use open government data. As defined by [17], facilitating conditions refer to which level an individual believes that organizational and technical infrastructure support the use of the system. By considering the study in the same OGD context, this study postulates this hypothesis:

$\mathrm{H}_{4}$ : Facilitating Conditions positively influence the intention to use OGD.

\section{Quality Factors and Behavioral Intention to Use}

\section{1) Information Quality}

According to [30], information quality measures the quality of the information provided by the information system. As for today, many scholars have conducted their researches in information quality in open data context [31] [33]. These studies in similarity highlighted few common characteristics of information quality.

In the open government data context, [10] adapted the ISSM to measure the quality factors that influence the intention to use OGD. They highlighted that preciseness of data, relevancy, quantity and actuality of data contributes to the intention to use OGD. Therefore, this study formulates this hypothesis:
H5: Information Quality has a positive relationship towards behavioral intention to use OGD.

\section{2) System Quality}

[18] defined system quality as a quality that relates to system performance and it is measured by perceptions of individuals. Meanwhile, [21] identified system quality as a system with free-bugs, consistency of user interface, ease of use, documentation quality and maintainability. In the OGD context, [30] highlighted that system quality measures the quality of the systems' information processing performance from the engineering-oriented view.

Though, [10] in their study found that system quality does not have a significant relationship with the use of OGD, from the developers' and journalists' perspectives. In contradiction, [27] proved that system quality has a significant relationship to the intention to use e-filing tax system. This is supported by findings of another study by [34] which highlighted that system quality has a positive relationship to the intention and use of e-learning system. The hypothesis in this study is:

H6: System Quality has a positive relationship towards behavioral intention to use OGD.

\section{3) Service Qualit}

According to [18], service quality means overall support which is delivered by the service provider, either the IS department in the organization, outsource or internet service provider (ISP). In the open data context, the owner of the data (or the respective government agency) can be considered as a service provider. [10] in their paper highlighted that service quality has a positive effect on the use of OGD. Therefore, this study formulates this hypothesis:

H7: Service Quality has a positive relationship towards behavioral intention to use OGD.

\section{Quality Factors and Trust to Open Data Website}

[35] highlighted in their paper that information quality has a significant correlation with trust in e-government context. [36] stated in their paper that information quality is related to the quality of information which concerns on the government activities and assessed by public perception based on the accuracy and completeness of the $\mathrm{e}$ government system. Therefore, [35] stated that information quality can improve the trust towards e-government system. Furthermore, [37] highlighted that positive information quality should influence trust. Hitherto, [11] in their study highlighted that information quality has a direct relationship towards trust to open data websites. 
As mentioned by [36], system quality and service quality is one of the important factors that influences consumer's trust in the context of e-commerce. In contrary, [23] highlighted that trust enables citizens to believe that egovernment can provide the best service to the citizens. Yet, [36] mentioned that the existence of system quality such as reliability and speed of access can improve the trust of the e-government from the users' perspectives. Similarly, [35] also mentioned that system quality and service quality is likely can improve the confidence towards the trust from the users' perspectives.

Therefore, this study postulates these hypotheses: H8: The higher the information quality in open data, the greater the trust towards the open data website.

$\mathrm{Hg}$ : The higher the system quality in open data, the greater the trust towards the open data website.

$\mathrm{H} 10$ : The higher the service quality in open data, the greater the trust towards the open data website.

\section{E. TRUST FACTORS}

Trust can be categorized into two: 1) trust to technology, 2) trust to government [11], [23]. Trust to government can be defined as citizens' beliefs towards the capability, integrity and generosity of the government agency which provides services to the nation [38]. Furthermore, trust to government can be formed from the good governmentnation relationship [36]. In OGD context, [11] highlighted that citizen will likely trust the government if they believe that government can perform its obligations and commitments in providing best service to them.

Likewise, users will probably trust the open data website if they have faith that internet technology is safe and reliable to be used. In general, trust to open data can be concluded as a common view of trust in government agency and trust in the reliability of technology [11], [39]. This initiates these hypotheses:

H11: Trust to government influence the trust to open data website.

H12: Trust to technology influence the trust to open data website.

\section{F. Trust to Open Data Website and Behavioral Intention to Use}

In the OGD context, trust has a significant relationship towards the open data website [11], [14]. This is also similar to other studies that have been conducted in different areas such as e-government [26], [39]-[41], e-commerce [42] and internet banking [43], [44]. Therefore, in this study, this hypothesis is constructed:

H13: Trust to open data website has a positive relationship towards behavioral intention to use OGD.

\section{CONCLUSION}

Open data enables governments, citizens, and civil society and private sector organizations to make better- informed decisions. Effective and timely access to data helps individuals and organizations develop new insights and innovative ideas that can generate social and economic benefits, improving the lives of people around the world. Practically, open data can empower governments, citizens, and civil society and private sector organizations to work toward better outcomes for public services. Many governments in the world have taken a very good initiative to implement open government data in their countries. Hence, since the platform is already available, the level of use of datasets provided need to be assessed to ensure that it can benefit the citizens.

\section{References}

Open Data Barometer - World Wide Web Foundation. [Online]. Available: http://webfoundation.org/our-work/projects/opendata-barometer/. [Accessed: 13-Jun-2017].

The World Wide Web Foundation, "Open Data Barometer - Global Report Second Edition," 2015.

Priyankar Bhunia, "Brief look at Open Government Data in 6 ASEAN countries | 2017-02-03 | OpenGovAsia," OpenGov, 2017. [Online]. Available: http://www.opengovasia.com/articles/7336brief-look-at-open-government-data-in-6-asean-countries. [Accessed: 21-Feb-2017].

[4] E. Kalampokis, E. Tambouris, and K. Tarabanis, "A classification scheme for open government data: towards linking decentralised data," Int. J. Web Eng. Technol., vol. 6, no. 3, p. 266, 2011.

[5] Open Data Institute, "A Guide to the Open Data Maturity Model," pp. 1-32, 2015.

[6] M. Janssen, Y. Charalabidis, and A. Zuiderwijk, "Benefits, Adoption Barriers and Myths of Open Data and Open Government," Inf. Syst. Manag., vol. 29, no. 4, pp. 258-268, 2012.

[7] J. C. Bertot, U. Gorham, P. T. Jaeger, L. C. Sarin, and H. Choi, "Big data, open government and e-government: Issues, policies and recommendations," Inf. Polity, vol. 19, no. 1-2, pp. 5-16, 2014.

[8] J. Gurin, "Big data and open data: what's what and why does it matter? | Joel Gurin," Public Leaders Network, 2014. [Online]. Available: https://www.theguardian.com/public-leadersnetwork/2014/apr/15/big-data-open-data-transform-government. [Accessed: 08-Apr-2017].

[9] The World Wide Web Foundation, “Open Data Barometer - Global Report Fourth Edition," 2017.

[10] C. Cartofeanu and D. Macrinici, "Evaluating the Success of eGovernment OpenData Platform at Increasing Transparency in Moldova: from the Perspectives of Journalists and Developers," 2017.

[11] W. R. Fitriani, A. N. Hidayanto, P. I. Sandhyaduhita, and B. Purwandari, "Determinants of Intention to Use Open Data Website: An Insight from Indonesia," PACIS 2017 Proc., 2017.

[12] S. Saxena and M. Janssen, "Examining open government data (OGD) usage in India through UTAUT framework," Foresight, vol. 19, no. 4, pp. 421-436, 2017.

[13] A. Zuiderwijk, M. Janssen, and Y. K. Dwivedi, “Acceptance and use predictors of open data technologies: Drawing upon the unified theory of acceptance and use of technology," Gov. Inf. Q., vol. 32, no. 4, pp. 429-440, 2015.

[14] M. C. Jurisch, M. Kautz, P. Wolf, and H. Krcmar, "An International Survey of the Factors Influencing the Intention to Use Open Government," 2015 48th Hawaii Int. Conf. Syst. Sci., pp. 2188-2198, 2015.

[15] I. Ajzen, "The theory of planned behavior," Organ. Behav. Hum. Decis. Process., vol. 50, no. 2, pp. 179-211, 1991. 
[16] F. D. Davis, "Perceived Usefulness, Perceived Ease Of Use, And User Acceptance," MIS Q., vol. 13, no. 3, pp. 319-339, 1989.

[17] V. Venkatesh, M. G. . Morris, G. B. . Davis, and F. D. . Davis, "User acceptance of information technology: Toward a unified view," MIS Q., vol. 27, no. 3, pp. 425-478, 2003.

[18] W. Delone and E. McLean, "The DeLone and McLean model of information systems success: a ten-year update," J. Manag. Inf. Syst., vol. 19, no. 4, pp. 9-30, 2003.

[19] J. Jewer and D. R. Compeau, "Understanding IS Adoption and Success: Integration of IS Success and Technology Adoption Research Full Paper," no. 1991, pp. 1-10, 2017.

[20] W. H. DeLone and E. R. McLean, "Information Systems Success: The Quest For The Dependent Variable," Information systems research, vol. 3, no. 1. pp. 60-95, 1992.

[21] P. B. Seddon, "A Respecification and Extension of the DeLone and McLean Model of IS Success," Information Systems Research, vol. 8, no. 3. pp. 240-253, 1997.

[22] M. Albashrawi and L. Motiwalla, "When IS Success Model Meets UTAUT in a Mobile Banking Context: A Study of Subjective and Objective System Usage," 2017.

[23] T. S. H. Teo, S. C. Srivastava, and L. Jiang, "Trust and Electronic Government Success: An Empirical Study," J. Manag. Inf. Syst., vol. 25, no. 3, pp. 99-132, 2008.

[24] Y.-S. Wang and Y.-W. Liao, "Assessing E-Government Systems Success: a Validation of the Delone and Mclean Model of Information Systems Success," pp. 356-366, 2006.

[25] J. H. Wu and Y. M. Wang, "Measuring KMS success: A respecification of the DeLone and McLean's model," Inf. Manag., vol. 43, no. 6, pp. 728-739, 2006.

[26] O. K. Lean, S. Zailani, T. Ramayah, and Y. Fernando, "Factors influencing intention to use e-government services among citizens in Malaysia," Int. J. Inf. Manage., vol. 29, no. 6, pp. 458475, 2009.

[27] N. L. Lu and V. T. Nguyen, "Online Tax Filing-E-Government Service Adoption Case of Vietnam," Mod. Econ., vol. 07, no. 12, pp. 1498-1504, 2016.

[28] P. Thomas, "Information systems success and technology acceptance within government organization," 2006.

[29] N. P. Rana, M. D. Williams, Y. K. Dwivedi, and J. Williams, "Theories and Theoretical Models for Examining the Adoption of EGovernment Services.," e-Service J., vol. 8, no. 2, pp. 26-56, 2011.

[30] A. Purwanto, M. Janssen, and A. Zuiderwijk, "Towards an Open Government Data Success Model: A Case Study from Indonesia," 17th Eur. Conf. Digit. Gov. - ECDG 2017, pp. 154-162, 2017.
[31] A. Vetrò, L. Canova, M. Torchiano, C. O. Minotas, R. lemma, and F. Morando, "Open data quality measurement framework: Definition and application to Open Government Data," Gov. Inf. Q., vol. 33, no. 2, pp. 325-337, 2016.

[32] Center for Open Data Enterprise, "Briefing Paper on Open Data and Data Quality,” no. April 2012, p. 14 pages, 2016.

[33] J. Umbrich, S. Neumaier, and A. Polleres, "Quality assessment and evolution of Open Data portals," Proc. - 2015 Int. Conf. Futur. Internet Things Cloud, FiCloud 20152015 Int. Conf. Open Big Data, OBD 2015, pp. 404-411, 2015.

[34] H. Mohammadi, "Investigating users' perspectives on e-learning: An integration of TAM and IS success model," Comput. Human Behav., vol. 45, pp. 359-374, 2015.

[35] R. Nulhusna, P. I. Sandhyaduhita, A. N. Hidayanto, and K. Phusavat, "The relation of e-government quality on public trust and its impact on public participation," Transform. Gov. People, Process Policy, vol. 11, no. 3, pp. 393-418, 2017.

[36] T. Wang, Y. Cao, and S. Yang, "Building the model of sustainable trust in e-government," Proc. - 2010 2nd IEEE Int. Conf. Inf. Financ. Eng. ICIFE 2010, pp. 698-701, 2010.

[37] A. I. Nicolaou and H. Mcknight, "Perceived Information Quality in Data Exchanges: Effects on Risk, Trust, and," vol. 17, no. 4, 2006.

[38] D. H. Mcknight, L. L. Cummings, and N. L. Chervany, "Initial Trust Formation in New Organizational Relationships," vol. 23, no. 3, pp. 473-490, 2016.

[39] L. Carter and F. Bélanger, "The utilization of e-government services: Citizen trust, innovation and acceptance factors," Inf. Syst. J., vol. 15, no. 1, pp. 5-25, 2005.

[40] F. Bélanger and L. Carter, "Trust and risk in e-government adoption," J. Strateg. Inf. Syst., vol. 17, no. 2, pp. 165-176, 2008.

[41] J.-H. Lee and C. Song, "Effects of trust and perceived risk on user acceptance of a new technology service," Soc. Behav. Personal. an ..., vol. 41, no. 3, pp. 587-598, 2013.

[42] F. Belanger, J. S. Hiller, and W. J. Smith, "Trustworthiness in electronic commerce: the role of privacy, security, and site attributes," J. Strateg. Inf. Syst., vol. 11, no. 3-4, pp. 245-270, Dec. 2002.

[43] E. Esmaili, M. I. Desa, H. Moradi, and A. Hemmati, "The Role of Trust and Other Behavioral Intention Determinants on Intention toward Using Internet Banking," Int. J. Innov. Manag. Technol., vol. 2, no. 1, pp. 95-100, 2011.

[44] Y. Sok Foon and B. Chan Yin Fah, "Internet Banking Adoption in Kuala Lumpur: An Application of UTAUT Model," Int. J. Bus. Manag., vol. 6, no. 4, pp. 161-167, 2011 